\title{
A Comprehensive Retrospective Study: Intestinal Parasites in Human in Van Province
}

\author{
Geniş Kapsamlı Bir Retrospektif Çalışma: Van Yöresinde İnsanlarda \\ Intestinal Parazitler
}

\author{
(1) Zeynep Taş Cengiz ${ }^{1}$, (1) Hasan Yllmaz ${ }^{1}$ (1) Yunus Emre Beyhan ${ }^{1}$, (1) Mutalip Çiçek ${ }^{2}$ \\ ${ }^{1}$ Yüzüncü Yll University Faculty of Medicine, Department of Parasitology, Van, Turkey \\ ${ }^{2}$ Ahi Evran University Faculty of Medicine, Department of Parasitology, Kırşehir, Turkey
}

Cite this article as: Taş Cengiz Z, Y1lmaz H, Beyhan YE, Çiçek M. A Comprehensive Retrospective Study: Intestinal Parasites

in Human in Van Province. Turkiye Parazitol Derg 2019;43(2):70-3.

\begin{abstract}
Objective: The aim of present study was to retrospectively determine the prevalence of intestinal parasites in patients, who were referred to Parasitology Laboratory in Van Yüzüncü Yll University, Faculty of Medicine during an 11-year period.

Methods: Stool samples of 69633 individuals admitted to the outpatient clinics in the hospital were initially evaluated with native-Lugol, and then by flotation, sedimentation, trichrome staining, modified acid-fast staining and ELISA methods.

Results: Twenty-four parasite species were identified in parasite-positive patients. At least one or more parasite species were found in $34.1 \%$ of all patients. The most commonly observed parasite was Blastocystis hominis (26.5\%). Among pathogen parasites, Giardia intestinalis (G. intestinalis) was detected in 9.3\%, Ascaris lumbricoides (A. lumbricoides) was detected in 2.5\%, Entamoeba histolytica/Entamoeba dispar in $0.8 \%$, Cystoisospora belli in $0.004 \%$, Fasciola hepatica in $0.04 \%$, Dicrocoelium dendriticum in $0.001 \%$, Strongyloides stercoralis in $0.001 \%$ and hookworm in $0.001 \%$ of the patients.

Conclusion: It was determined that, pathogen parasites such as $G$. intestinalis and A. lumbricoides were still observed at high rates in Van province, especially in children, and the problem of parasitosis is still continuing, although the prevalence of parasites has declined when compared to the previous years.
\end{abstract}

Keywords: Intestinal parasites, human, Van

Öz

Amaç: Bu çalışmanın amacı 11 yıllık bir süreçte Van Yüzüncü Yıl Üniversitesi Tıp Fakültesi Parazitoloji Laboratuvar'ına başvuran hastalarda intestinal parazitlerin prevalansını retrospektif olarak belirlemekti.

Yöntemler: Hastanemizin polikliniklerine başvuran 69633 hastanın dışkı örnekleri nativ-Lugol ayrıca gerek duyulduğunda flotasyon, sedimantasyon, trikrom ve modifiye asit-fast boyama ve ELISA metodu ile değerlendirilmiştir.

Bulgular: Pozitif bulunan hastalarda toplam 24 parazit türü saptanmıştır. En az bir ya da daha fazla parazit türü bütün hastaların \%34,1'inde belirlenmiştir. En sık saptanan parazit, Blastocystis hominis olmuştur. Patojen parazitlerden Giardia intestinalis (G. intestinalis) \%9,3, Ascaris lumbricoides (A. lumbricoides) \%2,5, Entamoeba histolytica/Entamoeba dispar \%0,8, Cystoisospora belli $\% 0,004$, Fasciola hepatica \%0,04, Dicrocoelium dendriticum \%0,001, Strongyloides stercoralis \%0,001 ve çengelli solucanlar \%0,001 oranında saptanmıştır.

Sonuç: Parazitlerin yayılış oranı geçmiş yıllara göre bir düşüş göstermiş olsa da özellikle çocuk yaş grubunda G. intestinalis ve A. lumbricoides gibi patojen parazitlerin Van yöresinde hala yüksek oranda görüldüğü ve parazitoz probleminin hala devam ettiği anlaşılmıştır.

Anahtar Kelimeler: İntestinal parazitler, insan, Van 


\section{INTRODUCTION}

Intestinal parasites are frequently observed in socio-economically underdeveloped or developing countries. The reasons for high parasitosis incidence include ecological factors such as abundant intermediate or reservoir hosts, shared habitat use or sharing nutrients and insufficiency in settlement infrastructure. Intestinal parasites are encountered more frequently among children when compared to adults, and may cause significant growth defects in children (1-4).

The prevalence of intestinal parasites varies among different regions in Turkey. The parasites are more frequently observed in socio-economically low regions such as Eastern and Southeastern Anatolia due to inadequate infrastructure, construction, defecation in open fields because of inadequate bathroom especially in rural areas, too many irrigation channels and the consumption of raw or undercooked watercress (5-8).

The aim of present study was to retrospectively determine the prevalence of intestinal parasites in patients, who were referred to Parasitology Laboratory in Van Yüzüncü Yll University, Faculty of Medicine during an 11-year period.

\section{METHODS}

The population of Van was 979.671 in 2007, literacy rate was $74.6 \%$, and the rate of university graduates was $6.4 \%$ (2000 general population census). Gross national product per capita and urbanization rate were below Turkey's average. However, the population growth rate was above Turkey's average (9).

For the present study, the ethic committee approval report was obtained from Yüzüncü Yll University, Faculty of Medicine, Non-Interventional Clinical Research Ethics Committee (date: February 27, 2014; decision number: 03). The results of the stool samples examined in Parasitology Laboratory in Van Yüzüncü Yll University, Faculty of Medicine, located at Van, Turkey, between 1997 and 2007 were evaluated retrospectively. The study samples included 69633 individuals (32033 female and 37600 male), who were admitted to the outpatient clinics in the hospital, and they were initially examined with native-Lugol, and then by flotation, sedimentation, trichrome staining, modified acid-fast staining and ELISA methods (10). For Entamoeba histolytica/Entamoeba dispar, the stool samples were stained by trichrome staining method and analyzed with ELISA [r-biopharm; RIDASCREEN ${ }^{\circ}$ Entamoeba (C 1701)] method for the antigen. The patients diagnosed with Fasciola hepatica (F. hepatica) or Dicrocoelium dendriticum ( $D$. dendriticum) eggs were asked if they had eaten a dish containing liver during the week before the examination. After warning the patients, not to eat such food in order to prevent false positive results, the stool samples were examined on three successive days. After this step, ELISA method (DRG Diagnostics; F. hepatica IgG ELISA) was used to analyze the results of $F$. hepatica positive patients.

Comparisons of the pathogen parasites' prevalence for age groups and gender were analyzed by independent two proportions $\mathrm{Z}$ (t) test. The statistical significance level was considered as $5 \%$ $(\mathrm{p}<0.05)$ (MINITAB; ver: 14).

\section{RESULTS}

In the present study, at least one or more parasite species were detected in 23729 (34.1\%) out of 69633 individuals. Parasite species were detected in $33.9 \%$ out of 32033 female and in $34.2 \%$ out of 37600 male individuals. There were no significant differences between the prevalence of total parasitosis based on gender or age variables (Table 1). One species of parasite was determined in $24.6 \%$, two species were determined in $5.7 \%$, three species were determined in 1\%, 4 species of parasites were determined in $0.3 \%$ of all patients. Prevalence of certain pathogen parasites by years are presented in Figure 1. Prevalence of the parasites were as follows: Blastocystis hominis (B. hominis) $26.5 \%$, Giardia intestinalis (G. intestinalis) $9.3 \%$, Entamoeba coli $6 \%$, Ascaris lumbricoides (A. lumbricoides) 2.5\%, Hymenolepis nana (H. nana) $1.2 \%$, Iodamoeba butschlii 1.6\%, Chilomastix mesnili $1.1 \%$, E. histolytica/E. dispar $0.8 \%$, Cryptosporidium spp. $0.7 \%$, Entamoeba hartmanni $0.7 \%$, Enterobius vermicularis $0.6 \%$ (in the stool), Endolimax nana $0.4 \%$, Trichuris trichiura (T. trichiura) $0.3 \%$,

\begin{tabular}{|c|c|c|c|c|c|c|c|c|c|c|c|c|}
\hline \multirow[t]{2}{*}{ Parasite species } & \multicolumn{2}{|c|}{$\begin{array}{l}\text { Total } \\
(\mathrm{N}=69633)\end{array}$} & \multicolumn{2}{|c|}{$\begin{array}{l}\leq 0-13 \text { years old } \\
(N=39600)\end{array}$} & \multicolumn{2}{|c|}{$\begin{array}{l}\geq 14 \text { years old } \\
\text { and older } \\
(\mathrm{N}=30033)\end{array}$} & \multirow[t]{2}{*}{$p$ values } & \multicolumn{2}{|c|}{$\sigma^{\prime}(\mathbf{N}=37600)$} & \multicolumn{2}{|c|}{ Q $(\mathrm{N}=32033)$} & \multirow[t]{2}{*}{ p values } \\
\hline & $\mathbf{n}$ & $\%$ & $\mathbf{n}$ & $\%$ & $\mathbf{n}$ & $\%$ & & $\mathbf{n}$ & $\%$ & $\mathbf{n}$ & $\%$ & \\
\hline E. histolytica/E.dispar & 589 & 0.8 & 292 & 0.7 & 297 & 1 & $<0.01$ & 317 & 0.8 & 272 & 0.8 & $>0.05$ \\
\hline Giardia intestinalis & 6504 & 9.3 & 4910 & 12.4 & 1594 & 5.3 & $<0.01$ & 3701 & 9.8 & 2803 & 8.8 & $<0.01$ \\
\hline Blastocystis hominis & 18460 & 26.5 & 13340 & 33.7 & 5120 & 17 & $<0.01$ & 5488 & 14.6 & 12972 & 40.5 & $<0.01$ \\
\hline Cryptosporidium spp.* & 92 & 0.7 & 92 & 0.7 & - & - & - & 48 & 0.6 & 44 & 0.7 & $>0.05$ \\
\hline Ascaris lumbricoides & 1720 & 2.5 & 994 & 2.5 & 726 & 2.4 & $>0.05$ & 909 & 2.4 & 811 & 2.5 & $>0.05$ \\
\hline Trichuris trichiura & 241 & 0.3 & 119 & 0.3 & 122 & 0.4 & $<0.05$ & 126 & 0.3 & 115 & 0.4 & $>0.05$ \\
\hline Hymenolepis nana & 859 & 1.2 & 676 & 1.7 & 183 & 0.6 & $<0.01$ & 522 & 1.4 & 337 & 1.1 & $<0.01$ \\
\hline Taenia saginata & 153 & 0.2 & 24 & 0.1 & 129 & 0.4 & $<0.01$ & 63 & 0.2 & 90 & 0.3 & $<0.01$ \\
\hline Fasciola hepatica & 25 & 0.04 & 8 & 0.02 & 17 & 0.1 & $<0.05$ & 2 & 0.01 & 23 & 0.1 & $<0.01$ \\
\hline Patients with parasite & 23729 & 34.1 & 13400 & 33.8 & 10329 & 34.4 & $>0.05$ & 12864 & 34.2 & 10865 & 33.9 & $>0.05$ \\
\hline
\end{tabular}




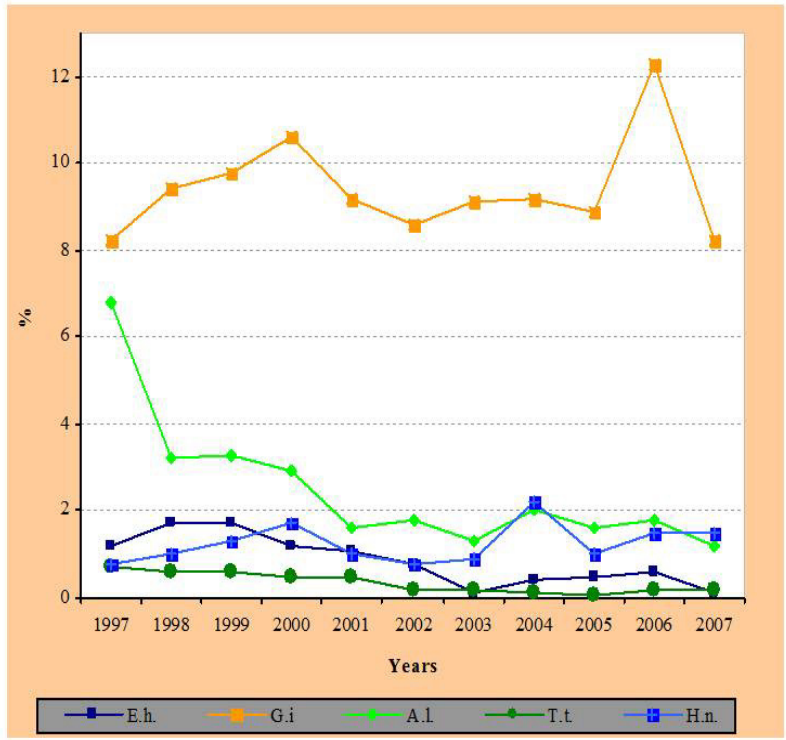

Figure 1. Prevalence of certain pathogen parasites by years (Abbreviations, E.h.: Entamoeba histolytica/E.dispar, G.i.: Giardia intestinalis, A.l.: Ascaris lumbricoides, T.t.: Trichuris trichiura, H.n.: Hymenolepis nana)

Taenia saginata (T. saginata) $0.2 \%$, Enteromonas hominis $0.1 \%$, Trichomonas hominis $0.07 \%$, F. hepatica $0.04 \%$, Retortamonas intestinalis $0.02 \%$, Dientamoeba fragilis $0.009 \%$, Cystoisospora belli (C. belli) $0.004 \%$, Strongyloides stercoralis $0.001 \%$, D. dendriticum $0.001 \%$, hookworm $0.001 \%$ and Trichostrongylidae spp. $0.001 \%$.

No statistically significant difference was found between the frequency of parasites based on age and gender groups. The difference between the frequency of E. histolytica/E. dispar $(\mathrm{p}<0.01), G$. intestinalis $(\mathrm{p}<0.01)$, B. hominis $(\mathrm{p}<0.01)$, T. trichiura $(\mathrm{p}<0.01), H$. nana $(\mathrm{p}<0.01)$, T. saginata $(\mathrm{p}<0.01)$ and F. hepatica $(\mathrm{p}<0.05)$ was statistically significant based on the age groups. The difference between the frequency of $G$. intestinalis, B. hominis, $H$. nana, T. saginata and F. hepatica was statistically significant based on gender $(\mathrm{p}<0.01$; Table 1$)$.

\section{DISCUSSION}

The prevalence of intestinal parasites depends on environmental and socioeconomic factors. These parasites are prevalent in underdeveloped agricultural and rural areas in tropical and subtropical regions $(11,12)$.

The socio-economic status and education level in eastern sections of East Anatolia Region, Turkey is notably low. Our hospital in Van province, which is located in this region, serves a large patient population. In previous studies conducted in Van province, it was reported that the rate of intestinal parasitosis was between 22.2$77.4 \%(6,8,13,14)$. The present study findings suggested lower rates $(34.1 \%)$ when compared to the results of certain previous studies conducted in Van province $(6,8)$.

The prevalence of intestinal parasites varies based on the region in Turkey. These parasites are less common (3.6-24.1\%) in western Turkey due to better socio-economic standards and educational levels (15-18). In previous studies conducted in eastern provinces in Turkey, the rate of intestinal parasitosis was reported as 17-
63.3\% (19-22). In previously conducted studies in Erciş district in Van province, parasitosis rate was determined as $77.4 \%$ (013 age group) and $77.1 \%$ (all age groups). In both studies, it was determined that $A$. lumbricoides was the most common parasite (respectively, $48.1 \%$ and $49 \%$ ) and the prevalence of F. hepatica was $0.6 \%$ and $2.4 \%(6,8)$. In the present study, it was found that the intestinal parasitosis rate was $34.1 \%$ and the most frequently determined pathogen parasite was $G$. intestinalis (9.3\%).

$B$. hominis, whose pathogenicity is still controversial, was identified as the most prevalent parasite $(26.5 \%)$ in the present study. It was observed that the prevalence of this parasite was between $0.05-13.1 \%$ in certain previous studies, which was lower when compared to the findings of the present study $(6,8,13,16-$ 18).

E. histolytica/E. dispar affects $10.2 \%$ of the world population (11). The prevalence of this parasite was reported to be below $12 \%$ in Van province $(13,14)$. In the present study, it was found that the prevalence of E. histolytica/E. dispar was as low as $0.8 \%$ (by age group, $\mathrm{p}<0.01)$. Giardiosis has a worldwide distribution. It is one of the ten most common intestinal parasites observed in humans $(11,12)$. In Van province, the highest rate for this parasite was determined as $21.3 \%$ in under 13 age group in 1998 (6). In the current study, the prevalence was found as $12.4 \%$ in under 13 age group (by age and gender, $\mathrm{p}<0.01$ ), and $9.3 \%$ in general population.

Literature review demonstrated that previously reported $C$. belli cases in Turkey included renal transplant, congenital diserythropoesis, AIDS and bronchoalveolar carcinoma patients $(23,24)$. In our hospital, $C$. belli was diagnosed in three patients (0.004\%); one immunosupressed and two immunocompetent patients.

Previously, A. lumbricoides was identified in $7.81-49.03 \%$ of the population in previous studies conducted in Van province $(6,8,13,14)$. The parasite was detected in $2.5 \%$ of the sample in our study, and this rate was very low when compared to previous studies conducted in Van province. F. hepatica was more prevalent with a rate of $2.4 \%$ in a previous study and lower rates were reported in other studies $(0.02-0.1 \%)(6,14,25)$. In the current study, the prevalence of this parasite was determined as $0.04 \%$.

In our region, the prevalence of important pathogenic parasites was usually below 2\% between 1997 and 2007. However, the spread rate of G. intestinalis was never below 8\% until 2007 (Figure 1).

\section{CONCLUSION}

In conclusion, it was determined that, pathogen parasites such as $G$. intestinalis and A. lumbricoides were still observed at high rates in Van province, especially in children, and the problem of parasitosis is still continuing, although the prevalence of the parasite declined when compared to the previous years.

\section{* Ethics}

Ethics Committee Approval: The study was approved by Yüzüncü Yll University Medical Faculty Non-Interventional Clinical Researches Ethics Committee.

Informed Consent: Retrospective study.

Peer Review: Externally and internally peer-reviewed. 


\section{* Authorship Contributions}

Concept: Z.T.C., Design: Z.T.C., H.Y., Y.E.B., Data Collection or Processing: Z.T.C., H.Y., M.Ç., Analysis or Interpretation: Z.T.C., H.Y., Y.E.B., Literature Search: Z.T.C., Y.E.B., Writing: Z.T.C., H.Y., Y.E.B.

Conflict of Interest: No conflict of interest was declared by the authors.

Financial Disclosure: The authors declared that this study received no financial support.

\section{REFERENCES}

1. Bartone CR. Reuse of wastewater at the San Juan de Miraflores stabilization ponds: public health, environmental, and socioeconomic implications. Bull Pan Am Health Organ 1985;19:147-64.

2. Engbaek K, Larsen SO. [A comparative socio-epidemiological study of families with Giardia lamblia, Entamoeba coli and Trichuris trichiura]. Ugeskr Laeger 1979;141:1128-31.

3. Gottlieb B, Reyes H, Trivino X, Vega J, Arriagada L, Hernandez J. [Enteroparasitosis in children in kindergarten. Comparative study according to socioeconomic level]. Rev Med Chil 1983;111:1035-8.

4. Salas SD, Heifetz R, Barrett-Connor E. Intestinal parasites in Central American immigrants in the United States. Arch Intern Med 1990;150:1514-6.

5. Özcel MA. Güneydoğu Anadolu Projesini Tehdit Eden Parazit Hastalıkları. İzmir:Ege University Printing House, 1995.

6. Yllmaz H, Goz Y, Guducuoglu H, Gul A. The problem of parasitosis in Erciş province, Van. Turkiye Parazitol Derg 1998;22:287-91.

7. Yilmaz H, Akman N, Goz Y. Distribution of intestinal parasites in two societies with different socio-economic status in Van. EJM 1999;4:16-9.

8. Yllmaz H, Goz Y, Bozkurt H. Distribution of fascioliosis and intestinal parasitosis in the Ziya Gökalp Primary School, Erciş, Van, Turkey. Turkiye Parazitol Derg 1999;23:28-31.

9. Anonymous. Regional Indicators. Prime Ministry Republic of Turkey. Turkish Statistical Institute 2006;383-95.

10. Garcia LS, Bruekner DA. Diagnostic Medical Parasitology. 3rd ed., Washington DC: A.S.M. Pres, 1997.

11. Abd El-Bagi ME, Sammak BM, Mohamed AE, Al Karawi MA, Al Shahed M, Al Thagafi MA. Gastrointestinal parasite infestation. Eur Radiol 2004;3:116-31.

12. Al-Braiken FA, Amin A, Beeching NJ, Hommel M, Hart CA. Detection of Cryptosporidium amongst diarrhoeic and asymptomatic children in Jeddah, Saudi Arabia. Ann Trop Med Parasitol 2003;97:505-10.
13. Yılmaz H, Cesur Y, Ozkaya E, Godekmerdan A, Gul A. Distribution of intestinal parasites 0-13 years old children admitted to Parasitology Laboratory of School of Medicine, Yüzüncü Yll University. Turkiye Parazitol Derg 1997;21:387-90.

14. Yllmaz H, Turkdogan K, Berktas M, Akman N, Tuncer İ, Algun E, Gul A, Goz Y. Distribution of intestinal parasites among 14 years old and older patients admitted to Parasitology Laboratory of Medicine Faculty. Turkiye Parazitol Derg 1997;21:49-54.

15. Alver O, Ozakin C, Yilmaz E, Akçağlar S, Töre O. [Evaluation of the distribution of intestinal parasites in the Uludag University Medical Faculty during a period of eight years.]. Turkiye Parazitol Derg 2005;29:193-9.

16. Dogan N, Demirüstü C, Aybey A. [The prevalence of intestinal parasites according to the distribution of the patients' gender and parasite species for five years at the Osmangazi University Medical Faculty]. Turkiye Parazitol Derg 2008;32:120-5.

17. Koksal F, Baslanti I, Samastı M. [A retrospective evaluation of the prevalence of intestinal parasites in Istanbul, Turkey]. Turkiye Parazitol Derg 2010;34:166-71.

18. Yaman O, Yazar S, Ozcan H, Cetinkaya U, Gozkenc N, Ates S, ve ark. [Distribution of intestinal parasites in patients presenting at the parasitologylaboratory of the medical school of Erciyes University between the years of 2005 and 2008]. Turkiye Parazitol Derg 2008;32:266-70.

19. Karaman U, Akkaya N, Aycan OM, Atambay M, Daldal N. Prevalance of intestinal parasites diagnosed by Malatya Public Health Laboratories Between 1997-2001. J Inonu Univ Med Fac 2004;11:25-8.

20. Kuk S, Erensoy A, Kelestimur N. Results of parasitological examination of stools in the Parasitology Laboratory of the Firat University Firat Medical Central inside the last year. Firat Med J 2006;11:113-5.

21. Ozbilgin A, Atambay M, Sali A. A study on intestinal parasites in Kars. Turkiye Parazitol Derg 1993;17:43-7.

22. Yildiz Zeyrek F, Ozbilge H, Zeyrek CD, Tasci S. Distribution of intestinal parasites in patients presenting at the Microbiology Laborotory of Medicine Faculty, Harran University. Turkiye Parazitol Derg 2002:26;27881.

23. Balcioğlu IC, Köse S, Kayran E, Limoncu ME, Kurt O, Ozbilgin A. [Isosporiasis in an immunocompetent child: case report]. Turkiye Parazitol Derg 2007;31:25-7.

24. Koru O, Araz RE, Yilmaz YA, Ergüven S, Yenicesu M, Pektaş B, ve ark. Case report: Isospora belli infection in a renal transplant recipent. Turkiye Parazitol Derg 2007;31:98-100.

25. Yilmaz H, Arabaci F, Ozdal N, Taş Z, Metin S, Orunç O. The prevalence of intestinal parasite infections among schoolchildren of Van province, Turkey. Trop Doct 2007;37:123-4. 